\title{
Teachers' Informal Learning via Social Networking Technology
}

\author{
https://doi.org/10.3991/ijet.v11i10.5908 \\ Radzuwan Ab Rashid ${ }^{1}$, Mohd Firdaus Yahaya ${ }^{1}$, Mohd Fazry A. Rahman ${ }^{2}$, Kamariah Yunus $^{1}$ \\ ${ }^{1}$ Universiti Sultan Zainal Abidin, Kuala Nerus, Terengganu, Malaysia \\ ${ }^{2}$ Shah Alam Community College, Shah Alam, Malaysia
}

\begin{abstract}
Discussion on teacher learning is often limited to a focus on formal professional development programmes. What and how teachers learn informally through their daily experiences is rarely explored. This research attempts to investigate how teachers engage in informal learning for their professional development when using Social Networking Site (SNS) technology. Data were generated using ethnographic approach whereby Facebook Timelines belonged to 22 English language teachers were observed for a period of six months. The analysis shows that the teachers frequently exchanged teaching related knowledge in their Timeline conversations and they received rich responses from both teaching and non-teaching Friends. This paper thus argues that social networking site, such as Facebook is a potential platform to engage teachers in informal learning for their professional development.
\end{abstract}

Index Terms-Teacher professional development, English language teaching, Malaysia, Facebook Timelines, teacher knowledge

\section{INTRODUCTION}

Teacher learning is an important issue that needs to be focused on in this fast changing era. This is to ensure that teachers will have knowledge and skills which are up to date to meet the current demands of the society. Many efforts are taken by the governments across the globe to encourage teacher learning so that they develop their professionalism. This is mostly done through professional development programmes in which specific knowledge and skills are introduced to teachers by experts during workshops and seminars, and the teachers are expected to apply this knowledge and skills in schools.

Informal learning which is defined by $[1, \mathrm{p} .5]$ as 'the activity involving the pursuit of understanding, knowledge or skill which occurs without the presences of externally imposed curricular criteria' in teachers' daily life should not be ignored. This is because teachers learn more through informal learning in their work place rather than in professional initial teacher education programmes [2]. Moreover, learning is 'social, situated in physical and social contexts, and distributed across persons, tools and activities' [2, p.5] thus teacher professional development needs to go beyond 'visible' development activities (coursework, workshops, seminars etcetera) and includes teachers' informal social and professional networks. Furthermore, given the affordances of the current technology, teachers interact in these networks at anytime and anywhere thus engage in continuous learning process [3], [4]. This paper aims to provide insights into the phenomenon of Malaysian English language teachers engaging in in- formal learning for their professional development using SNS technology.

\section{LITERATURE REVIEW}

\section{A. Collaborative Teacher Development}

Theoretical underpinning of collaborative teacher development is that individual development including higher mental functioning originates in social sources, which is the main tenet in sociocultural theory proposed by [5]. [6] argues that:

Any function in the child's cultural development appears twice, or on two planes. First it appears on the social plane, and then on the psychological plane. First, it appears between people as an interpsychological category and then within the child as an intrapsychological category

[5] views learning as situated in social activities. Through involvement in these social activities, human develops their knowledge and understanding which later internalized by them. This is parallel with the notion proposed by [7] that learners who participate in a wide variety of joint activities will have the opportunity to synthesize several influences into their new modes of understanding and participation.

Collaboration, in the context of teacher development, is defined by [8] as the act of teachers working together with others for a continued and organized investigation into teaching and learning aiming for professional growth. Johnston emphasizes that teachers must have or share control over the collaborative process and this reflects the need to give autonomy to teachers to decide on their participation and engagement in the activity.

Many teacher professional development activities require some form of collaboration either with peers, researchers or other people. This is mainly based on the sociocultural perspective that teachers learn best by interacting with others as it would help them to better understand their own beliefs and knowledge [9]. As argued by [8], when involved in collaborative activities, teachers are not only the consumers but also the producers of the knowledge about teaching. This is true as each teacher brings their own unique experiences with them and shares those experiences with their collaborative partners [10].

[8] puts forth four commonly adopted approaches and practices in collaborative teacher development. The first one is action research in which teachers engage in a smallscale, systematic and publicly reported research to change or understand their own classrooms and contexts. Second, is the narrative inquiry which involves teachers sharing 
stories of teaching experience that requires reflection and analysis. Third, is cooperative development in which peer teachers investigate their own work through carefully designed forms of non-judgmental discourse. Last but not least is exploratory practice which requires teachers to investigate problems in their classroom by integrating research procedure (i.e collecting data) into regular classroom work.

English language teacher collaborative partners usually involve fellow teachers (peers), subject teachers, university-based researchers, students, and others such as parents, administrators and material developers [8]. However, [8] points out that the collaboration does not always run smoothly especially when it involves university-based researchers due to inequities of power and status. Another challenge pointed by [8] is that this collaboration often receives lack of institutional supports and this could disappoint the teachers who have to invest time and energy to ensure the effectiveness of this collaboration.

\section{B. Teacher Knowledge}

Teachers' knowledge and teacher learning is complex in nature. Teachers need to learn constantly so that they acquire both the procedural (know how) and declarative (know what) knowledge that are relevant to the current demands in their work place. [11] puts forth a clear categorization of knowledge that teachers need to acquire for them to be fully developed. These are knowledge of subject matter (content knowledge), pedagogical content knowledge (the ways of representing subject knowledge appropriately for learners), knowledge of curriculum (grasp of the materials, resources and 'tools of the trade'), general pedagogical knowledge (broad understanding of management and organisation), knowledge of learners and their characteristics, knowledge of educational contexts (ranging from groupings, classrooms, schools, education authorities, national policies to wider communities and cultures), and knowledge of educational aims, purposes and values.

To acquire the knowledge, teachers need to be 'ready (possessing vision), willing (having motivation), able (both knowing and being able to do), reflective (learning from experience), and communal (acting as a member of a professional community)' [12, p.259]. However, optimum learning will only take place when the teachers are involved in activities that are sustained and continuous rather than episodic, and able to provide opportunities for teachers to collaborate with colleagues inside and outside the school [13, p.9].

The perspectives put forth by [12] and [13] affirm that effective teacher learning occurs when teachers learn about something meaningful to them which often takes place in their everyday life through interactions with people around them.

\section{Methodology}

This study employed ethnographic approach as its methodology. It examined participants' activities in a natural setting, which is their engagement in informal learning on Facebook Timeline as part of their daily routines. This is in contrast to the previous studies which examined teachers learning in Facebook Group created for the purpose of the research.

The participants were purposively sampled. They were 22 Malaysian English language teachers who actively post teaching-related postings on their Timelines. Participant observation was used as the main data generation method whereby the Facebook Timelines were observed over six months, from December 2012 to May 2013. This period covered one full academic semester and was long enough to capture the different kinds of experiences and challenges encountered in the teachers' professional lives. In addition to the participant observation, informal conversations took place occasionally to get further explanation from the participants regarding their discursive behavior on the Timelines.

Altogether, 178 teaching related Status updates were posted in the six month period which had attracted 1226 comments. The teaching related Status updates and Comments were analyzed using content analysis approach in order to identify the knowledge enquired by the teachers.

Detailed discussion on the methodological and ethical issues that arose in this study has been presented in [14]. In brief, the methodological issues were related to the observation as data generation method where being a participant observant was found to be more useful than being a non-participant observant even though it may influence the participants' behavior on the Timeline. The ethical issues were related to informed consent, which is whether the consent needs to be obtained from the participants as Timeline is a semi-public space. In this study, the informed consent was obtained as it was evaluated as the most ethical conduct in this context.

The data generation process can be divided into two phases. Phase 1 involved the observations of participants' Timelines and Phase 2 involved informal conversations with the participants. Even though the two phases are mentioned in sequence, it was a recursive process throughout the entire data generation period. For instance, some of the informal conversations were conducted in the same period during which the Timelines were observed.

\section{ANALYSIS AND Discussion}

From the 178 Status updates gathered, $59 \%(n=105)$ involve the seeking and sharing of teacher knowledge and the remaining $41 \%(n=3)$ are about other teaching related issues. In other words, more than half of the Status updates are used by the teachers to enhance their professional knowledge and this suggests the potential of Facebook as an informal platform for teacher professional development.

Further analysis shows that the teachers mainly exchange five types of teacher knowledge, which are content knowledge, knowledge of curriculum, general pedagogical knowledge, knowledge of learners and their characteristics, and knowledge of educational contexts. This is in contrast to Caribbean teachers, as revealed by [15], who only exchange general pedagogical knowledge when interacting on SNS.

Pedagogical content knowledge and knowledge of educational aims, purposes and values are not discussed on the teachers' Timelines, which suggests that they already have a good grasp of these types of knowledge. Another possible reason is that it is hard to discuss the pedagogical content knowledge through written communication on the site as it involves procedural explanation.

Examples of Status updates and Comments for each type of knowledge inquired by the teachers are shown in Table 
TABLE I.

EXAMPLES OF STATUS UPDATES AND COMMENTS OF TEACHER KNOWLEDGE

\begin{tabular}{|c|c|c|}
\hline Type of Teacher Knowledge & Example of Status Updates & Example of Comments \\
\hline $\begin{array}{l}\text { Content knowledge } \\
(33 \%, n=35)\end{array}$ & $\begin{array}{l}\text { To all the grammar nazi on my wall...help me to explain this: } \\
\text { a) Don't be hesitant to see the teacher on duty } \\
\text { b) Don't be hesitated to see the teacher on duty } \\
\text { Which one is correct?? I feel a is correct but I need explana- } \\
\text { tion. Thanx! } \\
\text { (Wafi/SU2) }\end{array}$ & $\begin{array}{l}\text { Don't hesitate or don't be hesitant. Hesitate } \\
\text { is a verb so you don't have to add be in front } \\
\text { (Wafi/SU2/C2) }\end{array}$ \\
\hline $\begin{array}{l}\text { Knowledge of curriculum } \\
(25 \%, n=26)\end{array}$ & $\begin{array}{l}\text { Need briefing!!! } \\
\text { School Based Assessment for English....all this while was } \\
\text { teaching upper secondary school. Now have to teach lower } \\
\text { secondary. SBA expert Cheng Chong Hung can you please } \\
\text { help me...? How to go about this whole thing?? } \\
\text { (Jaya/SU1) }\end{array}$ & $\begin{array}{l}\text { Try coordinating with other teachers teach- } \\
\text { ing English in the same form. Else coming } \\
\text { out with your own SBA sheets is very tax- } \\
\text { ing. Cannot use published materials. Cause } \\
\text { students can get the answers by buying and it } \\
\text { becomes invalid. } \\
\text { (Jaya/SU1/C3) }\end{array}$ \\
\hline $\begin{array}{l}\text { General pedagogical knowledge } \\
(16 \%, n=17)\end{array}$ & $\begin{array}{l}\text { Guys, how do you teach a big class? Do you divide them into } \\
\text { groups? What is the optimum number of students in a group? } \\
\text { (Hafiz/SU1) }\end{array}$ & $\begin{array}{l}\text { Yes, need to divide them into groups. Make } \\
\text { sure it should not exceed } 5 \text { members in the } \\
\text { group. Or else you will have the free rider. } \\
\text { (Hafiz/SU1/C3) }\end{array}$ \\
\hline $\begin{array}{l}\text { Knowledge of learners and their } \\
\text { characteristics } \\
(14 \%, n=15)\end{array}$ & $\begin{array}{l}\text { My students are to shy to speak in English... do you guys face } \\
\text { a similar experience? How do you tackle them? } \\
\text { (Liza/SU3) }\end{array}$ & $\begin{array}{l}\text { Give them fun activities! You can use songs } \\
\text { that they like as your teaching material. They } \\
\text { will forget their shyness when they enjoy the } \\
\text { song. } \\
\text { (Liza/SU3/C2) }\end{array}$ \\
\hline $\begin{array}{l}\text { Knowledge of educational contexts } \\
(11 \%, n=12)\end{array}$ & $\begin{array}{l}\text { Malaysian English language teachers need to improve English } \\
\text { up to BBC standard, but MOE is importing English language } \\
\text { teachers from USA??? So confusing... } \\
\text { (Ifa/SU8) }\end{array}$ & $\begin{array}{l}\text { Yep, we need to follow British English. } \\
\text { They are just here to support us with peda- } \\
\text { gogy. } \\
\text { (Ifa/SU8/C4) }\end{array}$ \\
\hline
\end{tabular}

As can be seen in Table 1, content knowledge is the most frequently exchanged knowledge on the teachers' Timelines $(33 \%, n=35)$. This is followed by knowledge of curriculum $(25 \%, \mathrm{n}=26)$, general pedagogical knowledge $(16 \%, n=17)$, knowledge of learners and their characteristics $(14 \%, n=15)$, and knowledge of educational contexts $(11 \%, n=12)$. As revealed during the informal conversations with the participants, they feel that Timeline is an appropriate space to exchange teacher knowledge, especially the content knowledge as it will also be beneficial to the non-teaching Friends. For instance, Wafi reported that she purposefully asked about the adjective hesitant on the Timeline as she wants to engage her Friends in vicarious learning. More importantly, the participants believe that their teaching Friends who are geographically distributed are able to respond to their enquiries at their own convenience.

The knowledge of educational contexts which range from groupings, classrooms, schools, education authorities, national policies to wider communities and cultures, is the least frequently sought on Facebook Timelines. This is perhaps because education authorities and national policies are sensitive issues in this country. In one of its recent circulation, Malaysian government forbids all the government servants to comment on government policies on a public space, such as social media. By avoiding from talking about sensitive issues on Timelines when engaging in informal learning, the teachers show that they are fully aware of how to strategically use SNS for their development without tarnishing their professional image. This finding resonates with [16] and [17] who reveal that teachers are being strategic when presenting themselves on SNS so that they are being perceived positively by other users.

Another characteristic of the teachers' informal learning on the Timelines is that they receive rich feedback from
Friends. The average number of Comment for teachingrelated Status updates is seven to eight. None of the Status update fails to attract Comments from other users. This suggests that the teachers were very supportive to one another when it comes to the enquiry of teacher knowledge. Interestingly, it was observed that the Comments came from both the teaching and non-teaching Friends thus enabling the teachers to receive multiple perspectives on the issues raised. In other words, Facebook serves as an 'affinity space' where the teachers interact with users from various background for their professional development [18], [19]. These non-teaching Friends mostly responded based on their experiences being a student or parents to schooling children.

\section{CONClusion}

It is evident that social networking sites serve as a potential platform to engage teachers in informal learning process. Given the affordances of the networking technology which allow quick and rich responses, the teachers prefer to seek teaching-related knowledge by asking their Facebook Friends rather than meeting their colleagues face-to-face. The teachers are also being selective in the types of teacher knowledge asked online so that they do not bring sensitive issues to the public site which might cause unintended consequences. By interacting on the networking site, the teachers attempt to expand teachingrelated knowledge for their professional development.

\section{RECOMMENDATION FOR FUTURE RESEARCH}

Future research may build on the finding that nonteaching Friends also contribute to the informal learning process engaged by the teachers. This is the finding that has not been anticipated from the start, thus it is not welldeveloped in this study. The informal conversations were only carried out with the teachers who frequently posted 
teaching-related issues on Timelines thus the views of the non-teaching Friends regarding the informal learning process are not scrutinized. It is recommended that future research explores the views of non-teaching Friends as they are individuals that play important roles in the teachers' informal learning on Timelines.

In addition, future studies could also take a longitudinal approach, for instance, monitoring the interactions in the informal learning process over a two-year period. Such longitudinal research would be useful for providing insights into the development of teachers' discursive practices and whether the teachers still grapple with similar sources of difficulty over time.

\section{ACKNOWLEDGMENT}

Special thanks to Dr. Mary Bailey and Dr. Jane Evison from the University of Nottingham, United Kingdom for supervising this research project.

\section{REFERENCES}

[1] Livingstone, D., Adults' Informal Learning: Definitions, Findings, Gaps and Future Research. Toronto: Ontario Institute for Studies in Education, 2001.

[2] Johnson, K., Second Language Teacher Education: A Sociocultural Perspective. London: Routledge, 2009.

[3] Rashid, R.A., \& Rahman, M.F., Social Networking Sites for Online Mentoring and Creativity Enhancement. International Journal of Technology Enhanced Learning, vol. 6, no. 1, pp. 3445, 2014 http://dx.doi.org/10.1504/IJTEL.2014.060024

[4] Nikolaou, A. \& Tsolakidis, C., Three Dimensional Virtual Environments as a Tool for Development of Personal Learning Networks. International Journal of Emerging Technologies in Learning, vol. 28, pp. 79-88, 2013.

[5] Vygotsky, L.S., Mind in Society: The Development of Higher Psychological Processes. Cambridge: Harvard University Press. 1978.

[6] Vygotsky, L. S., "The Development of Higher Forms of Attention in Childhood," in The Concept of Activity in Soviet Psychology, J. V. Wertsch, New York: Sharpe, 1981.

[7] John-Steiner, V \& Mahn, H., Sociocultural Approaches to Learning and Evelopment: A Vygotskian Framework. Educational Psychologist, vol. 31, no, 3, pp. 191-206, 1996. http://dx.doi.org/10.1080/00461520.1996.9653266

[8] Johnston, B., "Collaborative Teacher Development," in The Cambridge Guide to Second Language Teacher Education, A. Burns, \& J. Richards, Cambridge: Cambridge University Press, pp. 241-249, 2009.

[9] Burton, J., "Reflective Practice," in The Cambridge Guide to Second Language Teacher Education, A. Burns, \& J. Richards, Cambridge: Cambridge University Press, 2009, pp. 298-307.

[10] Rashid, R.A., Topic Continuation Strategies Employed by Teachers in Managing Supportive Conversations on Facebook Timeline.
Discourse Studies, vol. 18, no. 2, pp. 188-203, 2016. http://dx.doi.org/10.1177/1461445615623906

[11] Shulman, L.S., Knowledge and Teaching: Foundations of the New Reform. Harvard Educational Review, vol. 57, no. 1, 1-22, 1987. http://dx.doi.org/10.17763/haer.57.1.j463w79r56455411

[12] Shulman, L.S., \& Shulman, J.H., How and What Teachers Learn: A Shifting Perspective. Journal of Curriculum Studies, vol. 36, no. 2, pp. 257-271, 2004. http://dx.doi.org/10.1080/0022027032 $\underline{000148298}$

[13] McLaughlin, M.W. \& Talbert, J., Building School-Based Teacher Learning Communities. New York: Teachers College Press, 2006.

[14] Rashid, R.A., Exploring Methodological and Ethical Issues in Researching Teachers' Informal Learning on a Social Networking Site. Nottingham: The Nottingham Jubilee Press, 2014.

[15] Kamalodeen, V., Teacher Learning in an Online Social Networking Website. Caribbean Curriculum, vol. 22, pp. 133-155, 2014.

[16] Rashid, R.A., Wahab, Z., Yunus, K., Ismail, N.S., Yusof, N., Syed Omar, SNM., \& Latiff Azmi, M.N., English Language Teachers as a Dissenter on a Social Networking Site. International Journal of Applied Linguistic and English Literature, vol. 5, no. 4, pp. 72-78, 2016.

[17] Kimmons, R. \& Veletsianos, G., The Fragmented Educator 2.0: Social Networking Sites, Acceptable Identity Fragments, and the Identity Constellation. Computers and Education, pp. 292-301, 2014. http://dx.doi.org/10.1016/j.compedu.2013.12.001

[18] Rashid, R.A., Responding to 'Nurturing Global Collaboration and Networked Learning in Higher Education'. Research in Learning Technology, vol. 24: 31485, 2016. http://dx.doi.org/10.3402/ rlt.v24.31485

[19] Rashid, R.A., Rahman, M.F.A., \& Rahman, S.B.A., Teachers' Engagement in Social Support Process on a Networking Site. Journal of Nusantara Studies, vol.1, no. 1, 34-45, 2016.

\section{AUTHORS}

Radzuwan Ab Rashid is with the Faculty of Languages and Communication, Universiti Sultan Zainal Abidin, 21300 Kuala Nerus, Terengganu, Malaysia (email: radzuwanrashid@unisza.edu.my).

Mohd Firdaus Yahaya is with the Faculty of Languages and Communication, Universiti Sultan Zainal Abidin, 21300 Kuala Nerus, Terengganu, Malaysia (email: mohdfirdaus@unisza.edu.my).

Mohd Fazry A. Rahman is with the Shah Alam Community College, 40100 Shah Alam, Malaysia (email: fazryrahman@kksa.edu.my).

Kamariah Yunus is with the Faculty of Languages and Communication, Universiti Sultan Zainal Abidin, 21300 Kuala Nerus, Terengganu, Malaysia (email: kamariah@unisza.edu.my).

This work was supported by UniSZA and Malaysia Ministry of Higher Education under the SLAB/SLAI scheme. Submitted, 02 June 2016. Published as resubmitted by the authors on 09 October 2016. 